NORDISK MUSEOLOGI $1998 \cdot 2$, S. 29-40

\title{
MUSEUMSGENSTANDEN SOM RELIKVIE
}

\section{Camilla Mordhorst}

Der findes genstande, som vi tilagger serlig verdi. Nogle genstande er udfort $i$ kostbare materialer, andre er sjaldne. Endeligt findes de folelsesmassigt vardifulde genstande. Det er ting, som tilskrives en sentimental historie, ofte af mytologisk karakter. I àr 2000 er det planen at vise en anderledes udstilling i Odense, som udelukkende vil bestå af sådanne genstande. Vi har kaldt udstillingen Fynske relikvier.

Hvordan kan man skildre fynsk historie ved hjælp af genstande, uden at genstandene reduceres til illustrationer for en historie, som vi allerede kender uafhængigt af museets samling? Den problemstilling havde Mette Thelle og jeg os for øje, da vi i efteråret 1997 blev bedt om et oplæg til en udstilling $\mathrm{i}$ anledning af årtusindsskiftet. Som museumsinspektører ved Odense Bys Museer, som både rummer arkæologi, historie, kunst og biografihistorie var det oplagt at søge nye tværfaglige veje. Det blev til udstillingsoplægget Fynske relikvier', som her skal præsenteres. Arbejdet med udstillingen gav anledning til mere generelle overvejelser om genstandens rolle i udstillingen på det kulturhistoriske museum. Disse overvejelser er stadig skitseagtige og mangler kritisk prøvelse, men skal alligevel fremlægges i slutningen af denne artikel som stof til eftertanke.

\section{RELIKVIER}

I anledningen af årtusindskiftet viser udstillingen fynsk historie på en ny og overraskende måde. Genstandene er ikke udvalgt som repræsentanter for en generel kulturhistorisk udvikling eller som eksempler på fortidens unikke frembringer. Genstandene er alene udvalgt, fordi der til dem er knyttet en god historie fra regionen. Vi har kaldt disse genstande for fynske relikvier.

Relikviebegrebet blev allerede anvendt $\mathrm{i}$ det klassiske latin om ligrester, især af helgener. ${ }^{2}$ Siden udvidede begrebet sig til også at omfatte ting, som blot var kommet i berøring med helgen. Det var ærbødigheden for kristne helgener og martyrer, som skabte relikviedyrkelsen kun få hundrede år efter Kristus. Ved at besidde en rest af den hellige søgte man på håndgribelig vis at opnå kontakt med Gud. 
30 Efterhånden blev relikvierne tillagt alskens egenskaber. De kunne beskytte mod ulykker og skabe mirakler. Mængden af relikvier blev med tiden anseelig. Kirken tilskyndede relikviedyrkelsen ved at stille krav om, at hvert alter skulle indeholde et relikvie. Med reformationen blev relikvievæsenet officielt afskaffet i Danmark. Både den romersk-katolske og den græskkatolske kirke fastholder dog stadig relikviets religiøse betydning som en mulighed for at opnå kontakt med det guddommelige om end i modereret form (Vellev 1972).

\section{KULTURHISTORISKE «RELIKVIER»}

Trods reformationen er der stadig levn, som synes at besidde relikviets magiske egenskaber. Det gælder ikke blot fortsat de relikvier, som findes i landets middelalderlige kirker. Også historiske genstande kan besidde den magi at bringe beskueren $\mathrm{i}$ kontakt med det hinsides eller rettere sagt det fortidige. Det er genstande, der som de religiøse relikvier fortælles at have været i kontakt med det "guddommelige» i form af historiske helte og legender. Ud fra en bred forståelse af relikviebegrebet vil disse genstande kunne kaldes relikvier.

På Odense Bys Museer har vi en særlig forkærlighed for at samle genstande ind, som har relikvieværdi. I H. C. Andersens Hus og barndomshjem og Carl Nielsens Museum og barndomshjem kan folk træde ind og dyrke de berømte personer gennem genstande. Ligesom de religiøse relikvier ses genstandene som rester af det værdifulde hensvundne, man på håndgribelige måde forsøger at bevare kontakten med.

Det ligger ikke i genstanden selv, om den er et relikvie. En genstand bliver først et relikvie, når den bliver tilskrevet en særlig følelsesmæssig betydning. En lille lygtepæl lavet af min afdøde farfar af mønter og et fingerbøl har relikviestatus, men nok kun for mig. Andre genstande får relikviestatus for mange mennesker. De kan blive særdeles eftertragtede samlerobjekter. Det afspejler sig bl.a. i de priser, som genstandene kan opnå på det frie marked. I efteråret 1997 forsøgte Odense Bys Museer at erhverve en scrapbog med vers, tegninger og udklippede billeder lavet af $\mathrm{H}$. C. Andersen til den 2-årige Rigmor Stampe. Billedbogen, som blev udbudt på international auktion gik imidlertid for en pris af 4 millioner kroner til en privat amerikansk opkøber med henblik på videresalg (Jensen 1997). Det var en pris, kun få danske kunststykker kan opnå. ${ }^{3}$ Et kig i bogen vil vise, at værdien ikke alene kan tilskrives det kunstneriske niveau i H. C. Andersens private klip og klister. Det virkeligt eftertragtede ved scrapbogen er, at H. C. Andersen personligt har lavet den. Den er blevet et relikvie for berømtheden.

Det er dog ikke kun på de biografiske museer, at genstande med relikviestatus findes, selvom der i sagens natur findes særligt mange af dem der. De fleste museer viser sig ved nærmere eftersyn at rumme genstande med relikviestatus. I 1972 blev en del sølvtøj til en anseelig økonomisk og historisk værdi stjålet fra Odense Bys Museer. Af alt det værdifulde var imidlertid det største tab Thomas Kingos sølvbæger - ikke fordi det var belagt med ædelsten eller var historisk enestående som kunsthåndværk, men fordi det havde tilhørt den berømte salmedigter. Bægeret var blevet et relikvie for Thomas Kingo.

Der findes også genstande, som tilsyneladende kun er indsamlet for deres relikvi- 


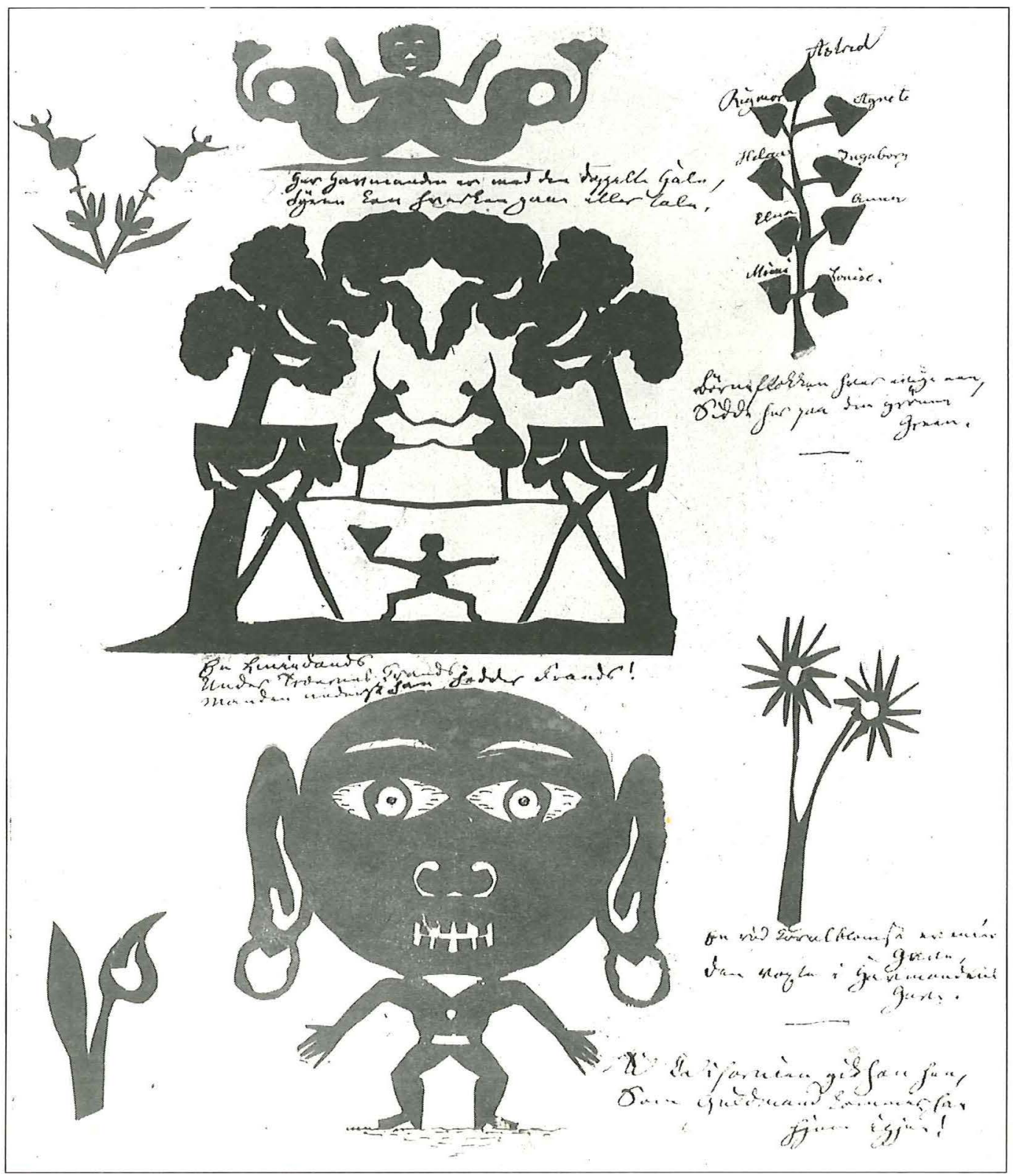

H. C. Andersen lavede skrapboger til sine venners born. I dag salges bogerne for skyhoje priser. Et kig $i$ Rigmor Stampes skrapbog viser; at vardien ikke alene kan tilskrives det kunstneriske nivean $i H$. C. Andersens private klip og klister. Det virkeligt eftertragtede ved bogen er, at $H$. C. Andersen personligt har lavet den. Den er blevet et relikvie for beromtheden. Foto, Odense Bys Museer 1998. 


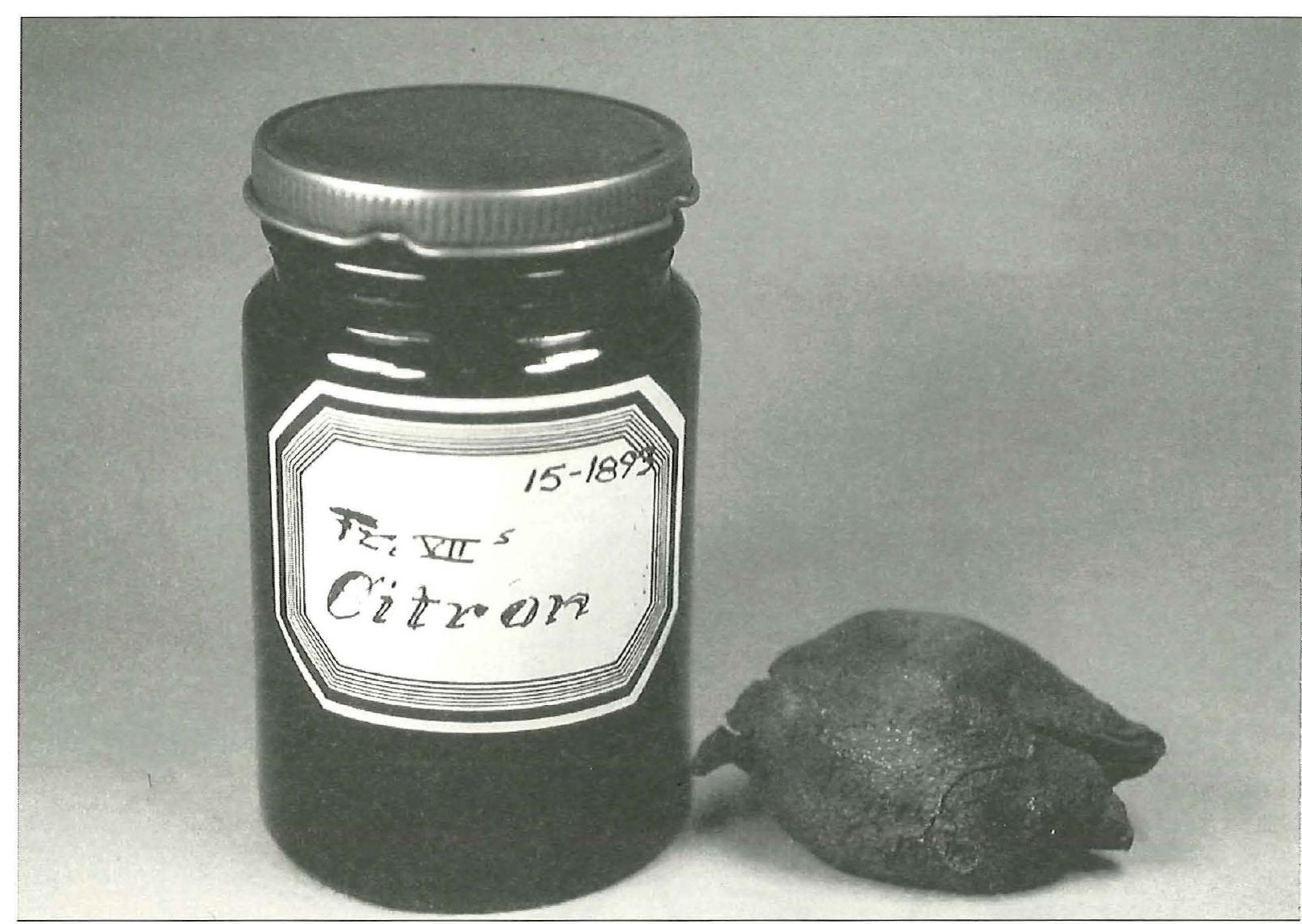

Frederik VII nedskod egenhandigt en citron $i$ Nasbyhoved Skov lige uden for Odense. Den indgik $i$ sin tid $i$ Odense Bys Museers samling, fordi der til den er knyttet en god historie. Nu forer citronen et hengemt liv $i$ museets magasiner, maske fordi den ikke formar at leve op til historievidenskabelige krav om kulturhistorisk representativitet og dokumentation. Foto, Odense Bys Museer 1998.

eværdi. De fører som oftest en hengemt tilværelse på museets magasiner, fordi de ikke formår at leve op til historievidenskabelige krav om kulturhistorisk repræsentativitet og dokumentation. På Odense Bys Museer har vi bl.a. en cigarstump røget af Winston Churchill, da han i triumftog kom gennem byen efter 2. verdenskrig. En gammel indtørret citron nedskudt af Frederik VII i Næsbyhoved Skov lige uden for Odense hører til i samme gruppe af hengemte relikvier.

En genstand kan opnå relikviestatus, men den kan også miste den igen. På Nationalmuseets magasiner opbevares en hønsefjer. Den havde nok forlængst været smidt ud, hvis ikke det havde været for en lille seddel, hvorpå det påstås, at fjeren stammer fra selveste Ærkeenglen Gabriels højre vinge. Fra Det kongelige Kunstkammers dage er fjeren efter streng videnskabelig metode blevet bestemt som englefjer (Behrend 1970). I dag opbevares fjeren ikke for dens relikviestatus, men som belærende eksempel på tidligere tiders værdsatte skatte.

En genstand kan også pludselig opnå status af relikvie. Monica Lewinskys helt almindelige blå selskabskjole har eksempelvis fået denne status og blevet kaldt «et relikvie helt i særklasse med Veronikas 2000 år gamle svededug» (Kerte 1998). 
For lige meget om de famøse pletter på den blå kjole virkeligt stammer fra verdens mægtigste mand, præsident Bill Clinton, så er kjolen blevet et eftertragtet samlerobjekt, om ikke andet så på grund af den mediebevågenhed, kjolen er blevet tildelt.

\section{UDSTILLINGENS IDÉ}

I Fynske relikvier vil vi sætte de enkelte historiske genstande i centrum og den betydning, som de gennem tiden er blev tillagt. På udstillingen vil man ikke kun kunne se de «rigtige» religiøse relikvier. På Odense Bys Museer har vi blandt andet en æske fra Sanderum kirkes alterbord med femten relikvier af apostle, biskopper, martyrer, jomfruer, en konge samt fra Kristi grav. Også de mere profane relikvier vil kunne ses. Helt nye og gamle relikvier vil blandes mellem hinanden, alle med tilknytning til den fynske historie. En nålepude syet af H. C. Andersen vil præsenteres på udstillingen. I en anden montre ses guldberlokkerne fra Ringe Museum, der efter sigende er de sidste rester af det omsmeltede guld fra guldhornene (Henriksen 1980). Det er ting, som er ladet med betydning og følelser i kraft af de historier, som knytter sig til dem.

På udstillingen vil relikvierne blive udstillet enkeltvis i deres montre uden anden baggrundsillustration. For det er relikviet og dets historie, som giver os adgang til historien. Vi vil fortælle historie med historier (von Plessen 1993). Fynske relikvier vil på den måde skabe indblik $\mathrm{i}$ den fynske historie, ikke overblik. Relikviet må ikke reduceres til illustration for større sammenhænge eller indordnes under hinanden i betydningshierarkier. Hvert enkelt relikvie er unikt og fungerer uafhængigt af hinanden som medie mellem os og det uopnåelige, hvad enten det er Gud eller historien.

\section{DE GODE, IKKE NØDVENDIGVIS SANDE HISTORIER}

At gå til historien ved hjælp af relikvier kan ikke kaldes en nutidig historievidenskabelig tilgang. Historikerens kildekritiske metode sættes ud af spillet, fordi tingenes bevislige sammenhæng med de begivenheder, som de refererer til, er ligegyldig, så længe de af eftertiden er blevet tilskrevet en autentisk værdi. Fynske relikvier vil blive en udstilling fuld af gode (måske indbyrdes modstridende) historier fremfor en udstilling, der forsøger at vise een videnskabeligt baseret historie. Som videnskabeligt uddannede fagfolk vil vores opgave være at bevidne genstandenes fine museale afstamning og historiernes sandsynlighed. Men det vil for en gangs skyld ikke være vores ekstrakt af historien, som de besøgende skal forholde sig til, men alle de mere eller mindre velkendte gode historier, som også findes langt uden for museets mure.

En pistol og et sølvkors på Svendborg Museum er de sidste rester af Elvira Madigans og Sixten Sparres ulykkelige kærlighed (Jansen 1995). Det er en god historie, som for nutiden bliver et historisk orienteringspunkt for udødelig kærlighed i den kollektive erindring (Nora 1989) 4 og på den måde synes langt mere vedkommende og relevant end væsentlige økonomiske og politiske begivenheder i følge den videnskabelige historie.

Fynske relikvier tager sit udgangspunkt i den erkendelse, at vores historiske bevidsthed ikke alene lader sig beskrive som en 
34 lang række faktiske begivenheder arrangeret af den sagligt kyndige $i$ et kronologisk forløb. Vores historiske bevidsthed er i lige så høj grad og måske mere præget af personlige erindringer og fortalte historier og legender. $\mathrm{Og}$ erindringen og de gode historier knytter sig ofte til genstande. Helt tilbage til amuletten og den første kristne relikviedyrkelse findes tanken om, at man kan få kontakt med det uopnåelige gennem tingene (Vellev 1972). At det uopnåelige har ændret sfære fra det religiøse til det profane, fra guderne til historien, ændrer ikke på det forhold.

\section{MUSÉE SENTIMENTAL}

Idéen til Fynske relikvier er inspireret af den tyske kurator Marie-Louise von Plessen og den schweiziske installationskunstner Daniel Spoerris udstillingsrække Musée Sentimental (von Plessen; Spoerri 1981, von Plessen 1993). Den første Musée Sentimental blev vist på det nyåbnede Centre Pompidou i Paris i 1977. I alfabetisk orden kunne man opleve sentimentalt opladede genstande, som formidlede rendyrket fransk nationalhistorie: Edith Piafs sorte kjole, Rimbauds rejsekuffert, en nøgle til Bastillen, Marie Antoinettes strikkepinde og Dantons barbergrej ved siden af kejserinde Eugénies knælange silkestrømper. På grund af besværet med at rejse i karet bar hun knælange strømper under en kort frakke. Kritikere troede, at de udstillede genstan- de var falske og historierne, nogle udstillerne havde digtet. Det på trods af, at alle genstandene og deres historier var af fineste museale afstamning. Siden fulgte Musée Sentimental de Cologne og Musée Sentimental de Prusse i henholdsvis Köln og Berlin efter samme princip. Udstillingerne gjorde ved deres bevidst alfabetisk encyklopædiske princip op med den traditionelle kronologiske måde at fremstille historien på. Ved hjælp af anekdoter og associationer blev velkendte videnskabelige ordensprincipper brudt. Udstillingerne forårsagede således «et åndeligt trafikchok», som fik de besøgende til at åbne øjnene op for det, de faktisk så fremfor det, de forventede se.

Fynske relikvier er vores version af princippet bag Musée Sentimental. Vi har ikke Napoleons hat eller Marie-Antoinettes strikkepinde, men den fynske historie kan opbyde lige så følelsesmæssigt værdifulde genstande, fordi den fynske historie også har sine helgener, helte og legender, som spiller en afgørende rolle $\mathrm{i}$ den hjemlige nationale erindring.

\section{UDSTILLINGENS FORM}

Udstillingens genstande er udvalgt uafhængigt af hinanden. Deres status som relikvier fra den fynske historie er det eneste, som binder dem sammen på udstillingen. De er med andre ord en specifik gruppe af genstande, som på grund af deres unikke karakter og deres tilstede-

Relikvier syner sjaldent af meget. Det er den tilskrevede betydning, som giver relikvierne deres vardi. Esken her fremtrader normest anonymt, men den indeholder resterne af jomfruer og martyrer, apostle og biskopper, en konge og lidt fra Kristi grav. Esken blev fundet $i$ Sanderum Kirkes alterbord $i$ 1895. Siden har den befundet sig på Odense Bys Museer.

Foto, Odense Bys Museer 1998. 


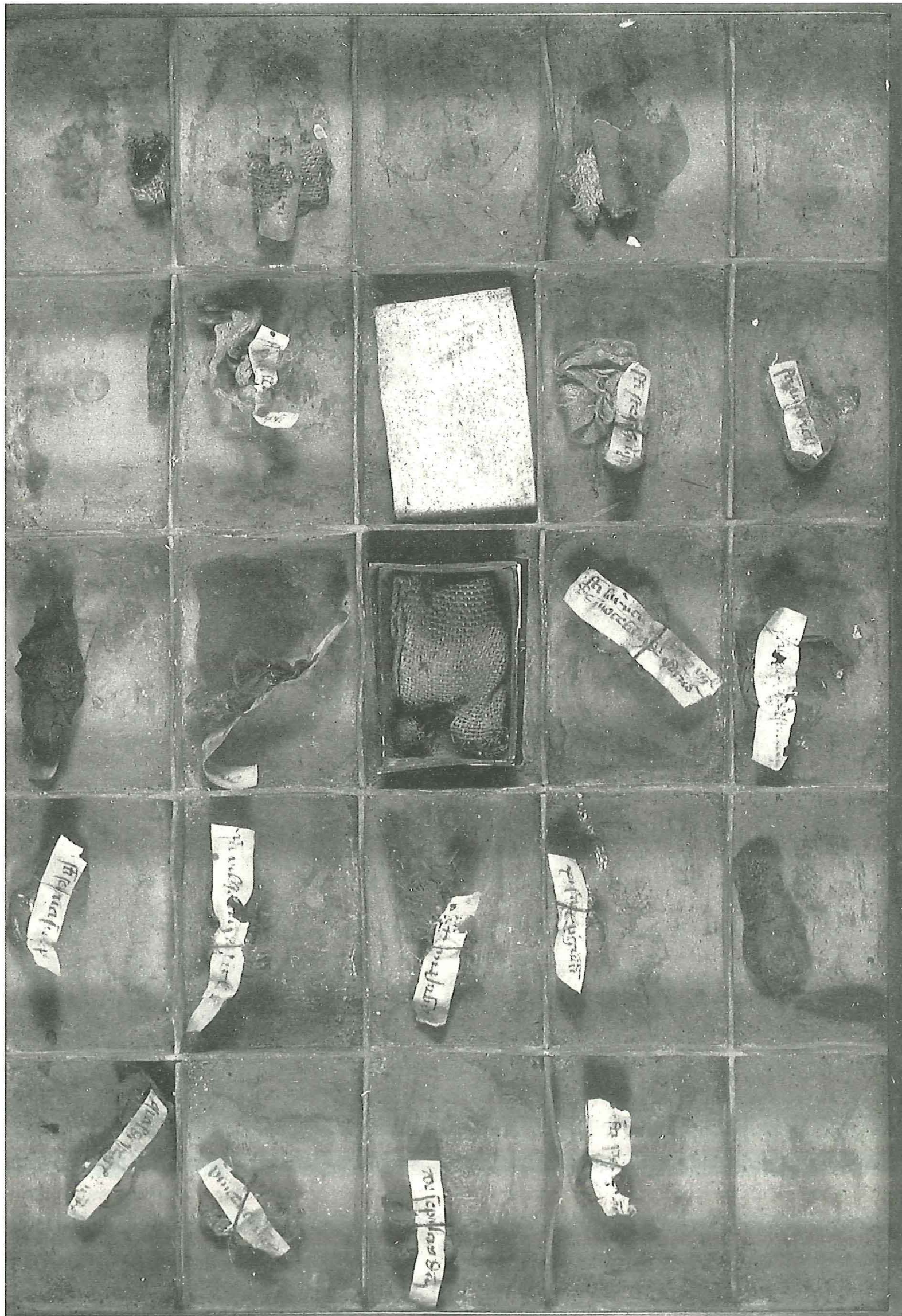


36 værelses påpegning af eftertidens værdsættelse tildeles en særlig historisk betydning. Genstandenes indbyrdes uafhængighed gør, at de skal udstilles hver for sig i hver sin montre. Og montrerne skal ikke foregive nogen sammenhæng, men alene fungere som understregning af det enkelte relikvies unikhed. Derfor skal montrerne ikke være ens. Gamle vil blive blandet med nye. Nogle genstande er efterhånden smeltet sammen med deres opbevaringssted, det gælder for eksempel guldberlokkerne, som opbevares $\mathrm{i}$ en skibskiste. Andre genstande vil blive placeret i gamle samtidige montre, andre igen kræver udformning af nye montrer.

Ved valg og udformning af montrerne bliver ekstern bistand påkrævet - en kunstner, som ideelt set kan både møbelhåndværket og samtidig har forståelse for erindringens betydning og xstetiske udsagnskraft. En arkitekttegnet helhedsløsning vil være uheldig, fordi det vil modgå hele udstillingens idé om at præsentere de fynske relikvier i deres særegenhed, hvor intet er over eller ved siden af genstandene.

Odense Bys Museers egne samlinger vil med sin bredde skabe et solidt fundament for udstillingens emne. Andre væsentlige fynske relikvier må indlånes fra regionens øvrige museer og kirker. Det kan også være, at relikvierne skal hentes længere vejs fra, fordi de trods deres tilknytning til Fyn har fundet ophold et andet sted.

Udstillingens historiefremstilling er ikke traditionel og derfor vil den vante kronologiske opstilling være uhensigtsmæssig. Kronologien vil medføre et udviklingsforløb i den fynske historie, som vi ikke kan eller vil vedgå os. ${ }^{5}$ Hvilken orden, som skal erstatte den kronologiske på udstil- lingen, er endnu ikke bestemt. Associationsprincippet ville være en mulighed, fordi det radikalt bryder med nutidens principper for videnskabelig systematik. ${ }^{6}$ En beslægtet historie eller en visuel lighed vil i så fald være det ordenskriterium, som gør, at to relikvier placeres i nærheden af hinanden. Andre ordner kan dog vise sig mere velegnet. Her må udstillingens kunstner også tages med på råd.

Relikvier, montrer, tekst og lys i de historiske rum. Det er udstillingens komponenter. Hverken mere eller mindre.

\section{GENSTANDENES ITALESATTELSE}

Idéen med Fynske relikvier er som næunt at skildre den fynske historie på en ny og overraskende måde, så den besøgende ikke falder hen i vishedens vaner, men får øjnene op for de gode historier i historien. Udstillingsoplægget har imidlertid også et mere internt museumsfagligt sigte. Med udstillingen vil vi give et bud på en anden relation mellem genstande og historier, således at genstandene af den besøgende opleves som nødvendige. Man kan hævde, at ambitionen er forfejlet, eller slet og ret unødvendig, fordi det jo er præsentationen af de kulturhistoriske genstande, som er udstillingen på det kulturhistoriske museum. Men udstillingen er andet og mere end det. Udstillingen er et medie, hvor tingene arrangeres udfra en overordnet fortælling, som enten kan manifestere sig som en bestemt orden, eller som en sideløbende tekst/ og eller illustration.

Ambitionen med den kulturhistoriske udstilling er selvsagt at formidle indsigt $\mathrm{i}$ kulturhistorien, men genstande taler ikke. De må italesættes. Det er således den tilskrevne historie, som giver genstanden 
dens relikviestatus. Ligeledes er det den kronologiske orden på ethvert museum, som gør, at vi vurderer den enkelte genstand ud fra dens historiske tilknytningsforhold. Og på samme måde er det illustrationen bagved genstanden, som henleder vores opmærksomhed ved en særlig egenskab ved genstanden.

\section{GENSTANDENES NØDVENDIGHED ELLER MANGLEN PA SAMME}

I udstillinger, hvor historien søges fremstillet ved hjælp af en bestemt orden, er genstandene helt nødvendige, for uden genstande kan der ikke skabes nogen orden. Der skal kort sagt være noget at ordne. Ligesom ordnen er afhængige af genstandenes tilstedeværelse, er genstandene afhængige af en orden. For det er ordnen, som bestemmer, hvilke betydningsindhold vi skal tillægge genstandene. De berygtede pilespidser på rad og række i kronologisk orden gør eksempelvis, at vi indlæser de enkelte pilespidser i et kulturhistorisk udviklingsforløb. Man kunne også vælge at opstille pilespidserne efter æstetiske kriterier. Dermed betones helt andre egenskaber ved genstandene som form og farve. ${ }^{7}$ At genstandene ikke selv "taler", men er afhængige af en tilskrevet fortælling, kan også ses ved et historisk tilbageblik. Uden kendskab til ordnen, blive udstillingens budskab uaflæseligt, og man står tilbage med en bunke skrammel. Renæssancens raritetskabinetter er eksempelvis ofte blevet miskrediteret for deres "brogede mangfoldighed" (Rasmussen 1979) og mangel på videnskabelig systematik. Den engelske museolog, Eilean Hooper-Greenhill, viser imidlertid i sin ph.d.afhandling (Hooper-Greenhill 1992), hvorledes renæssancens samlinger er strengt systematisk ordnet, men ud fra en helt anden rationalitet. Det kræver med andre ord kendskab til ordenen at forstå genstandene, at kunne give dem navn (Foucault 1966).

I udstillinger, hvor fortællingen ligger i teksten, som dermed udpeger, hvilke genstande som skal vises, anfægtes genstandenes nødvendighed i udstillingen. Man kender de udstillinger på, at den ene genstand let vil kunne udskiftes med en anden af samme type, uden at udstillingens overordnede fortælling forstyrres, fordi genstandens rolle i udstillingen er som illustration for en tekstlig sammenhæng. Genstandene bliver således sekundære i forhold til det som egentligt formidles, nemlig en historie som fungerer uafhængigt af genstandenes tilstedeværelse. Teksten fremfor tingene bliver det egentlige omdrejningspunkt i udstillingen. Måske er det derfor, det ofte er så trættende at gå på museum. Der er den umådelige lange tråd, som skal følges og følges, og man må ikke slippe den, ${ }^{8}$ for så bliver udstillingen uaflæselig.

Fynske relikvier indtager i denne sammenhæng en særstatus som udstilling. Her er genstandene en nødvendig, men ikke tilstrækkelig betingelse, fordi udstillingen hverken kan fungere uden genstande eller tekst. Og sammenknytningen mellem genstande og tekst er lige så uløselig, som den er arbitrær. For det ligger hverken i genstanden eller i teksten, at de hænger sammen, men netop i de tilskrevne sammenhænge opstår genstandens særlige værdi, dens relikviestatus. I Fynske relikvier er genstandene således nødvendige, men de kan ikke stå alene. Magien opstår, fordi de tilskrives historier, som genstandene selv 
38 bliver medier for. Omvendt vil historierne nok kunne stå alene, men uden kraft og saft, fordi de også henter deres værdi fra de tilknyttede genstande. Genstandene materialiserer så at sige historierne for os.

\section{ET PROJEKT TAGER SIN BEGYNDELSE}

Fynske relikvier er på flere måder et uafsluttet projekt. Udstillingen må realiseres, og det bliver unægteligt spændende, om de besøgende vil acceptere idéen om genstandenes nye status, eller om de blot vil opleve udstillingen som det pulterkammer, ethvert museum står i fare for at ende som. Men Fynske relikvier er også et forskningsprojekt om genstandens funktion i udstillingen på det kulturhistoriske museum, der netop har taget sin begyndelse. Politisk handler det om at forsvare genstandens særegne formidlingspotentiale, som ikke kan bibringes af andre medier. Teoretisk handler det om at undersøge dette formidlingspotentiale.

\section{NOTER}

1. Store dele af udstillingsoplægget Fynske relikvier $i$ 2000 arr skrevet af Mette Thelle og jeg i efteråret 1997 er integreret i nærværende artikel.

2. Denne forståelse af relikviebegrebet er hentet fra Salmonsens Konversationsleksikon bd. 14 fra 1925.

3. De dyreste danske malerier overstiger sjældent 4 mill. kr. En enkeltstående undtagelse er dog Eckersbergs pariserscene fra Aqueduc de la Vanne, som blev solgt i år for 4,1 mill. kr. (Dwinger 1998).
4. Begrebet kollektiv erindring er en oversættelse af den franske historiker, Pierre Noras begreb memoire collective. Begrebet er udviklet ud fra erkendelsen af, at fortidsbearbejdelse ikke kun finder sted i videnskabelige miljøer, men foregår overalt. Nora ser et modsætningsforhold mellem historievidenskaben og den kollektive erindring. Historievidenskaben er mistroisk over for erindringen og dens egentlige opgave er at undertrykke og ødelægge erindringen (Nora 1989). Vores udstilling er et forsøg på at tage udgangspunkt i den kollektive erindrings gode historier frem for at lægge afstand til dem.

5. Bag enhver orden er en idé. Bag enhver form et indhold. I Kitte Wagner Nielsens og min specialeafhandling om den kulturhistoriske udstilling er det en hovedpointe, at en form aldrig kan være værdifri eller neutral, men i sig bærer et historisk betinget indhold. I specialeafhandlingen viser vi blandt andet, at den kulturhistoriske udstillings kronologiske orden er et udtryk for 1800-tallets udviklingstankegang. Den kronologiske orden tilfører således udstillingen et bestemt historiesyn, som har vist sig ude af stand til at rumme dette århundredes modernistiske erfaringer.

6. I Les mots et les choses (Ordene og tingene) viser den franske idéhistoriker, Michel Foucault, hvorledes en form for associationstankegang (han kalder det "antipatier og sympatier» mellem tingene) spiller en central rolle i renæssancens videnskabelige tankegang, som indgang til indsigt i Guds skaberplan.

7. En æstetisk orden af stenalderredskaber ses sjældent på kulturhistoriske museer. I Roskilde Museums nyåbende permanente udstilling har man taget hensyn til æstetikken i opstillingen af genstandene, blandet andet ved spydspidserne fra stenalderen. En overordnet kronologisk ramme i form af rumtekster fortæller dog, at vi befinder os i stenalderen, så tingenes tidsmæssige placering spiller stadig en central rolle. Faktisk er det svært at tænke historisk uden at tænke i kronologiske 
udviklingsforløb. Men kronologien er hverken neutral eller værdifri som orden. Den medfører, at andre former for historiske indsigt udelades. Historiske brud og atavismer har eksempelvis svært ved at vises ved hjælp af en kronologisk orden.

8. Formuleringen er hentet fra Torkil Funders essays om rejser, samlinger og udstillinger, som er udkommet i et særnummer af Dansk Tidsskrift for Museumsformidling, 1998.

\section{LITTERATUR}

Becker, Annesofie; Flindt, Willie: Museum Europa. Udstillingsprogram. Kbh. 1991.

Behrend, Rikke: Gabriels vingefjer. I: Skalk. Nr.1, 1970.

Dwinger, Joanna: Frisk farve på gamle lærreder. I: Politiken 23.8.1998.

Foucault, Michel: Les mots et les choses. Une archéologie des sciences humaines. Paris 1966.

Funder, Torkil: Museum. Essays om rejser, samlinger, udstillinger 1971-1996. Særnummer af Dansk Tidsskrift for Museumsformidling. Nr. 16, 1998.

Henriksen, Mogens Bo: Historien om guldberlokkerne. I: Ræthinge-Posten. Arsskrift for Ringe Museumsforening og Ringe lokalhistoriske forening. Ringe 1980.

Hooper-Greenhill, Eilean: Museums and the Shaping of Knowledge. London/ New York 1992. Jansen, Henrik: Her blev Danmark til! På besøg i historien, Fyn. Skrifter for Svendborg og Omegns Museum. Bd. 35. 1995.

Kerte, Jens: Starfuckeren Monica. I: Politiken 22.8.1998.

Mordhorst, Camilla; Nielsen, Kitte Wagner: Formens semantik - en teori om den kulturbistoriske udstilling. Roskilde 1996. (Afhandlingen er under udgivelse). Kortversion i Nordisk Museologi

1997:1, s. 3-18.

Mordhorst, Camilla; Thelle, Mette: Fynske relikvier i 2000 ar. Odense 1997.

Nora, Pierre: Between Memory and History. Californien 1989.

Rasmussen, Holger: Dansk museumshistorie. Hjørring 1979.

Vellev, Jens: Fra helgengraven. I: Skalk. Nr. 3, 1972.

von Plessen, Marie-Louise; Spoerri, Daniel: Le Musée Sentimental de Prusse - eine Ausstellung der Berliner Festspiele Gmbh in Berlin-Museum 16. aug. - 15. nov. 1981. Berlin 1981.

von Plessen, Marie-Louise: Af kærlighed til tingene. I: Den jyske historiker. Nr. 64. 1993.

\section{SUMMARY}

Funen Relics

Funen Relics is the title of a coming exposition at Odense Bys Museer. While working on the exposition several discussions have arisen on the issue of the necessity - or lack of it - of the object. In many expositions the object is used to illustrate a text, which can be read on large plates. The objects are therefore in a certain sense superfluous, since the message is perfectly understandable without their use. On the other hand it is impossible to let the object stand alone, because objects don't speak. They must be spoken for.

Funen Relics is an attempt to throw light upon the object by picking out a certain kind of object in this particular instance objects related to stories of immortal love, heroism, the spirit of self-sacrifice or other such mythical tales. We have chosen to call these objects relics, because like "proper» religious relics their very existence is sufficient to provoke strong emotions in us. In the exposition every relic 
CAMILLA MORDHORST

40 will have its own exhibition case and the story ascribed to the object will be written on

plates positioned beside it.

In Funen Relics the presence of the object is a necessary but not sufficient condition for its meaning to come across. The exposition cannot work unless both the objects and the texts are there. Funen Relics is therefore not only an exhibition but also a practical suggestion for an exhibition in which the objects become the necessary carriers of meaning.

Camilla Mordhorst er museumsinspektor ved Odense Bys Museer, Afd. for Viden og Formidling.

Cand.comm. i Kommunikation fra Roskilde

Universitetscenter og Europaisk Etnologi fra

Kobenhavns Universitet. Deltager i Museologisk

Netverk.

Adr. Overgade 48, DK- 5000 Odense C.

Fax +4565907376 